\title{
Transformation of Household Savings into Investments: The Country's Credit Potential
}

\author{
Molchanova L. A. ${ }^{1,}$, Khokhlova S. V. ${ }^{2}$, Basova N. V. ${ }^{2}$, Makarova E. B. ${ }^{3}$, Gyunther I. N. ${ }^{4}$ \\ ${ }^{1}$ Finance, Credit and Insurance Department, Russian Academy of Entrepreneurship, Russia \\ ${ }^{2}$ Department of Theory and Practice of State Control of the Institute of Public Administration and Civil Service, RANEPA, Russia \\ ${ }^{3}$ Finance and Credit Department, Institute of Economics, Management and Law, Russian State University for the Humanities, Russia \\ ${ }^{4}$ Finance and Customs Revenues Department, University of Cooperation, Economics and Law, Russia
}

Received April 15, 2021; Revised June 30, 2021; Accepted July 15, 2021

\section{Cite This Paper in the following Citation Styles}

(a): [1] Molchanova L. A., Khokhlova S. V., Basova N. V., Makarova E. B., Gyunther I. N. , "Transformation of Household Savings into Investments: The Country's Credit Potential" Universal Journal of Accounting and Finance, Vol. 9, No. 4, pp. 875 - 884, 2021. DOI: 10.13189/ujaf.2021.090433.

(b): Molchanova L. A., Khokhlova S. V., Basova N. V., Makarova E. B., Gyunther I. N. (2021). Transformation of Household Savings into Investments: The Country's Credit Potential. Universal Journal of Accounting and Finance, 9(4), 875 - 884. DOI: 10.13189/ujaf.2021.090433.

Copyright $\odot 2021$ by authors, all rights reserved. Authors agree that this article remains permanently open access under the terms of the Creative Commons Attribution License 4.0 International License

\begin{abstract}
The Russian economy's long-term growth is inextricably linked to an appealing and efficient investment process, without which it is impossible to upgrade output structurally and qualitatively, build market infrastructure, and boost local competitiveness. The pressing issue of adequate investment tools necessitates an active search for viable sources for domestic economy demands, which concretizes the problem of mobilizing the state's internal resources - the population's savings. According to the experience of countries with a high degree of economic development, population savings are the primary source of establishing the resource basis for ensuring long-term economic growth and development. The function of the domestic financial market in the process of converting savings into investments is examined in this article. It has been established that there is a link between the financial market and the investment process. Theoretical components of the essence of savings and how they are transformed into investments are exposed. The impact of household financial investment volumes on the country's economic development indicators is studied and the dynamics and structure of population savings in Russia. The issues surrounding the conversion of savings into investments are recognized and the directions for intensifying it to maximize the financial potential of savings for the implementation of investment programs.
\end{abstract}

Keywords Financial Market, Household Investment,
Transformation of Savings

\section{Introduction}

The savings of the population are an important investment source. As a result, monitoring the processes associated with the transformation of investment savings has theoretical and practical value.

Considerable attention is paid to the problem of deposits of the population in banks in the works of A. Marshall. In turn, the relationship between savings and investments, as well as factors affecting their needs, play an important role in the Keynes model, in which investments are defined as a part of income that was not used for consumption in the current period. That is, investments act in this case as the reverse side of the savings process.

The role of the financial domain is quickly increasing in postindustrial society. Along with the traditional function of effective redistribution of resources among the subjects of the real sector, this sphere begins to perform an independent function, which manifests itself in the use of immanent growth factors regardless of the conditions and lines of development of other economic sectors. It manifests itself in the creation of derivatives and the infrastructure that allows for their efficient use [Karlsson \& Tavassoli, 2018; Karwowski, 2018; Nikas et al., 2020; Trotta, 2018; Yan et 
al., 2019].

The financial sector's high yields force a reallocation of resources in its favor, which is reflected in its rapid growth rates. Experts estimate that daily transaction volume has gone from $\$ 1$ billion in the 1970s to \$3-4 trillion now, with the volume of goods-and-services trade only increasing by 50\% [Birru, 2019].

According to other economists, money savings are individual savings funds, which are part of labor income. Simultaneously, savings in a closed economy are virtually the only source of funds to the money market. Other institutional units may increase their investment or finance fiscal deficits through investments [Leung \& Ilsever, 2013; Obura \& Anyango, 2016].

Not almost all existing research on the problem of savings of the population goes beyond the analysis of their economic means-that is, the formation of available funds and their accumulation [Başok \& Sayer, 2020; McCorkle, 2020]. However, the economic essence of savings is not limited to the formation of free cash flow and its accumulation. Monetary incomes of the population as the savings do not stop their movement, but rather search for new the best forms of preservation and growth.

Thus, scientists interpret the category «savings» differently; most often, this term is understood as the system of economic relations between the subjects in terms of formation, saving, and spending financial resources [Bagautdinova et al., 2016]. Savings are the part of the monetary income of the population remaining after implementation of all current consumer expenses that are used to meet future needs [Nikolaeva et al., 2019; Tolstolesova et al., 2019].

Efficiency and balance of economic processes are achieved by a rational redistribution of the financial flows between business entities, government, and the public. Despite the relatively high dynamics of its formation in the past, the domestic financial market has ceased to be an active engine of transforming savings into investments because of global and domestic economic crises. Consequently, the formation process of a sufficient financial capacity for the investment activities of all economic entities has slowed down. According to this statement, a matter of great concern is enhancing the role of financial markets in investment transformation [Magugu et al., 2018; Sembiyeva et al., 2021].

The following features characterize the modern mechanism of attraction of the population savings in the process of economic growth in Russia: while economic agents search for available sources of investment financing, a significant part of the savings accumulated in the form of national and foreign currency [Moșteanu, 2019].

The problem of finding the successful development of the financial market and especially of the saving market, reflected in scientific works of scientists and practitioners, among them [Deryagin et al., 2019; Dmitrieva \& Romasheva, 2020; Dudukalov et al., 2020; Goryainova et al., 2020; Ignatova et al., 2019; V. Ivanova et al., 2020; V.
N. Ivanova et al., 2019; Bakharev et al., 2020; Kantarbayeva \& Mustafin, 2020; Kashirskaya et al., 2020; Movchan \& Yakovleva, 2019; Pogosyan, 2019; Puryaev, 2020; Suryono et al., 2019; Takhumova et al., 2018; Vigliarolo, 2020; Prischepa et al., 2020; Yemelyanov et al., 2019; Yumashev et al., 2021].

Although a significant number of scientific papers are devoted to defining the content and features of the functioning of the financial market, certain questions regarding its role in the implementation of the investment process and the transformation of investment savings.

When the expansion and modernization of the national economy require significant amounts of financial resources, the value of the financial market increases on the basis that only it can provide effective redistribution of capital within the framework of the economic system [Korableva et al., 2020]. Simultaneously, the potential of the financial market in the context of savings attraction, along with the cash accumulations of enterprises, forms the basis for resource support for the investment's implementation in Russia.

The purpose of the study is to determine the financial market's role in transforming savings into investments in the context of financial and economic instability in the country. Achieving this goal requires the following tasks: establishing a connection between the developments of the financial market and the activation of the investment process and identifying the problems of transformation of savings into investments in Russia in terms of a crisis.

\section{Research Methods}

The business cycle is an economic activity characterized by changes in macroeconomic variables produced by business system uncertainty. Many approaches exist for analyzing behaviors and circumstances that influence the occurrence of a business cycle. One of the most efficient approaches for analyzing business and economic challenges is the mathematical method [Alam et al., 2021; Utama \& Kunnawuttipreechachan, 2021]. In the study, statistical and financial data characterizing the level of Russian financial market development, taking into account the peculiarities of the transformation of population savings into investments, are used. Herewith, in this case, comparison, analysis, synthesis, logical modeling was also used.

\subsection{The Role of Savings in the Financial Market: A Brief Review of Opinions and Judgments}

The financial market and the investment process are related closely. Moreover, the successful functioning of the financial market as a whole and the investment process, in particular, cannot be imagined without savings. Savings are first transformed into financial investments in the financial market and subsequently into real investments, bringing income for future savings (Figure 1).

Thus, I can assume that savings and investments are interconnected. 
The matter of savings was always the center of attention of scholars of economic science. The basis for identifying the content of the term "savings" was the idea of Adam Smith about the consumption part of income for certain categories of citizens (for workers - wages; landlords rent; entrepreneurs - profit). According to Smith, savings don't limit the effective demand because, through investment, they come into the sphere of consumption.

David Ricardo was more critical about savings. In his opinion, the capital of a specific person cannot grow simply by "non-consumption" [Korshunova, 2020].

J.M. Keynes noted that households' decisions on savings based on utility maximization, consequently, consumption increases as income for a certain time remains stable, leading to a higher level of savings [Shynkaruk et al., 2018]. Scientists proved that the volume of investment depends on a number of factors. First, the intensity of investment is affected by the interest rate on loan capital, and the marginal propensity interest rate is affected by the borrowed funds. Also, J.M. Keynes proves the rule that is known as "the investment multiplier of Keynes." The multiplier concept is central to Keynes' theory because it tells that an increase in investment by a certain amount leads to an increase in income greater than the increase in investment. Thus, investment has a "multiplier effect" on aggregate demand.

The reason for this phenomenon, according to J.M. Keynes, is a "fundamental psychological law" when consumption is growing with increasing income, but to a less extent. During these investigations, J. M. Keynes introduced the concept of marginal propensity to consume and save, the willingness to invest, the preference over liquidity, etc. He considered that one of the conditions stimulating investment activity is the formation of effective demand, in which he distinguished two varieties: consumer and investment.

Overall, the Keynesian theory argues that the growth of savings in the economic sense means a reorientation of funds from the purchase of articles of consumption into investment goods (investments). The equality of savings and investment is one of the prerequisites for sustainable economic growth. Considering the excess of savings over investment, production factors have not been fully used. When investment demand gets ahead of the amount of savings, you can come "overheating economy," growing inflation, etc.

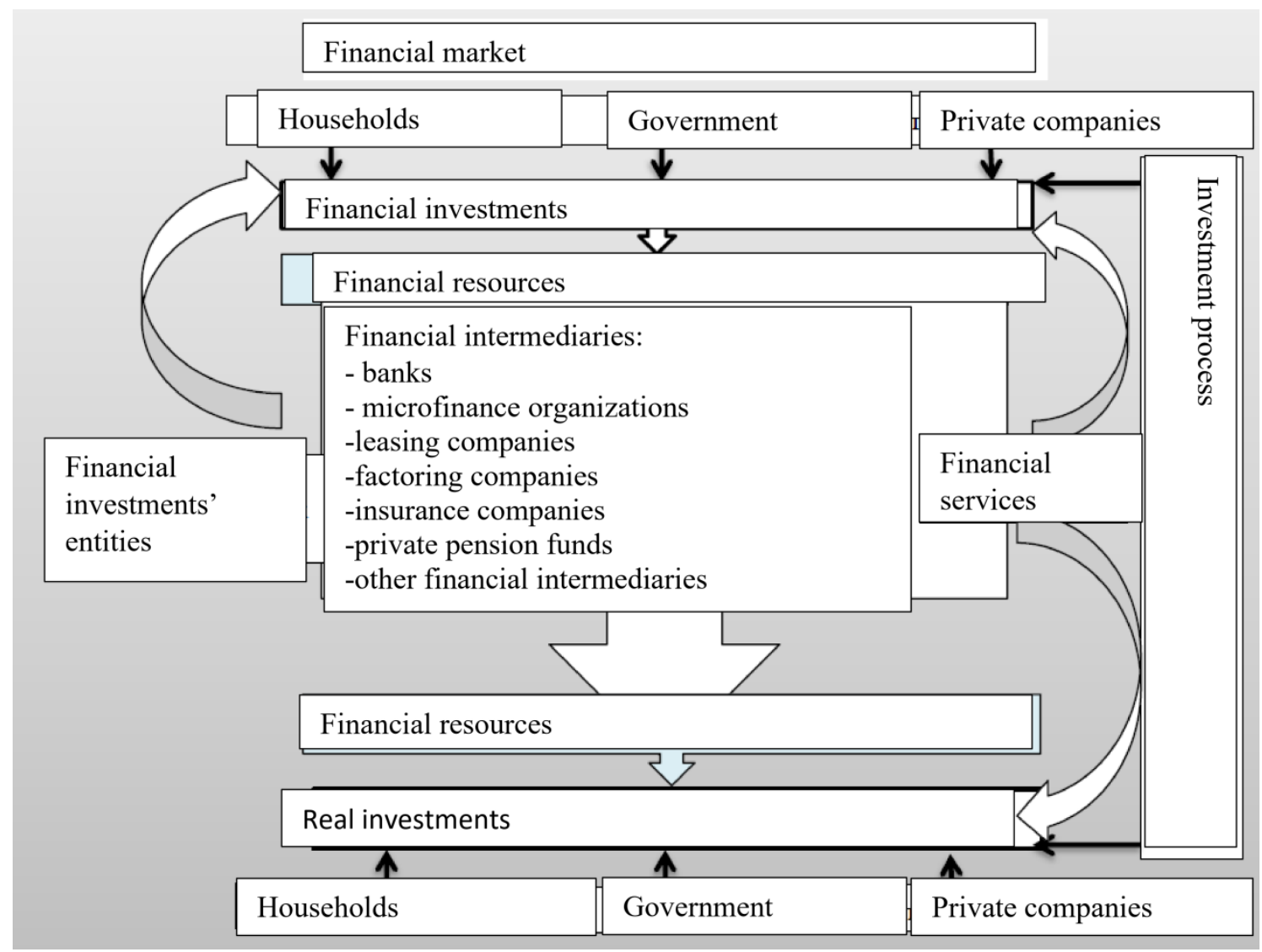

Figure 1. The connection between the financial market and the investment process [Zadoia, 2017] 
Among the local representatives of contemporary economic science L. F. Orlov, I. V. Maratkanova, and several others revealed the problem of the role of savings in society's economic and social growth most deeply. Scholars have noted the importance of increased population savings for the Russian economic, financial, social, and even political system in their scientific works. Small amounts of savings and the slow rate of their increase are the main barrier to financial market development and economic growth in general [Globa, 2021; Korshunova, 2020]. The scientists also noted that only a small proportion of personal savings goes directly to finance the investment needs of the entrepreneurial activities of the households.

\subsection{Key Indicators Affecting the Level of Savings in Russia and Leading Countries in Terms of Economic Development}

The problem of finding investment resources characterizes the current state of the domestic economy. To this aim, enterprises conduct more and more active research about financing sources to meet their investment needs. Despite the positive trends in the banking sector, it is necessary to note the objective financial insolvency of most domestic banks to ensure adequate volumes of long-term lending to investment processes in the economy. Simultaneously, the powerful and real financial potential, which is concentrated among the population, remains underused. World practice shows that the population's savings are the most sustainable investment resources [Lee \& Lin, 2018].

The main factor in the formation of household savings is the level of income. However, it should be noted that the volume of savings is also affected by several other circumstances - the level of taxation, deposit and credit interest rates, the demographic structure of the population, etc. (Table 1-3).

A review of international data about indicators that directly or indirectly affect the formation of savings of the population of leading countries vary by the level of economic development, according to a sample provided by the Federal State Statistics Service (FSSS), indicates significant differences. In particular, in the ranking of countries by GDP as a whole for 2019, Russia is in third place out of seven and GDP per capita for the same period, only in sixth place. Also, the USA and China have the first and second places in the GDP and GDP, per capita, respectively.

Significant importance in the research on the factors affecting the investment base formation is paid to the monetary aggregate M2 (M2 = M1 + time deposits, balances in national currency on accounts of time deposits and other funds of the population attracted for a time, non-financial and financial (except credit) organizations being residents of the Russian Federation).

Table 1. Gross Domestic Product

\begin{tabular}{|c|c|c|c|c|c|c|c|c|}
\hline \multirow{2}{*}{ Country } & \multicolumn{4}{|c|}{ GDP, billions of US dollars } & \multicolumn{4}{c|}{ GDP per capita, US dollars } \\
\cline { 2 - 9 } & $\mathbf{2 0 1 7}$ & $\mathbf{2 0 1 8}$ & $\mathbf{2 0 1 9}$ & $\mathbf{2 0 2 0}$ & $\mathbf{2 0 1 7}$ & $\mathbf{2 0 1 8}$ & $\mathbf{2 0 1 9}$ & $\mathbf{2 0 2 0}$ \\
\hline $\begin{array}{c}\text { Russian } \\
\text { Federation }\end{array}$ & 3881 & 4016 & 5578 & 1473.58 & 11325 & 11279 & 11441 & 10037 \\
\hline USA & 18707 & 19485 & 19391 & 20932.75 & 51933 & 52319 & 53128 & 63416 \\
\hline $\begin{array}{c}\text { United } \\
\text { Kingdom }\end{array}$ & 2824 & 2925 & 2622 & 2710.97 & 51536 & 42039 & 42514 & 40406 \\
\hline Germany & 4022 & 4100 & 3678 & 3803.01 & 45412 & 45923 & 46747 & 45733 \\
\hline France & 2739 & 2856 & 2583 & 2598.91 & 41374 & 41969 & 42567 & 39907 \\
\hline Japan & 5350 & 5443 & 4872 & 5048.69 & 47163 & 47660 & 48556 & 47200 \\
\hline China & 11222 & 12015 & 14093 & 14722.84 & 6497 & 6894 & 7329 & 10484 \\
\hline
\end{tabular}

Table 2. Indicators characterized the features of the savings formation in Russia and leading countries in terms of economic development

\begin{tabular}{|c|c|c|c|c|c|c|c|c|c|}
\hline \multirow{2}{*}{ Country } & \multicolumn{3}{|c|}{ M2, billion US dollars } & \multicolumn{3}{|c|}{ Disposable income, billion US dollars } & \multicolumn{3}{|c|}{ Population savings, \% of GDP } \\
\hline & 2017 & 2018 & 2019 & 2017 & 2018 & 2019 & 2017 & 2018 & 2019 \\
\hline Russian Federation & 659 & 711 & 733 & 307 & 336 & 322 & 27 & 26 & 27 \\
\hline USA & 13951 & 14112 & 14478 & 725 & 882 & 844 & 19 & 18 & 19 \\
\hline United Kingdom & 3018 & 3179 & 3172 & 438 & 451 & 451 & 12 & 14 & 14 \\
\hline Germany & 3141 & 3256 & 3392 & 458 & 497 & 502 & 27 & 27 & 28 \\
\hline France & 2296 & 2313 & 2429 & 384 & 402 & 404 & 22 & 23 & 22 \\
\hline Japan & 8949 & 9015 & 9130 & 382 & 772 & 349 & 27 & 28 & 28 \\
\hline China & 25611 & 27805 & 27920 & 502 & 541 & 584 & 46 & 47 & 46 \\
\hline
\end{tabular}




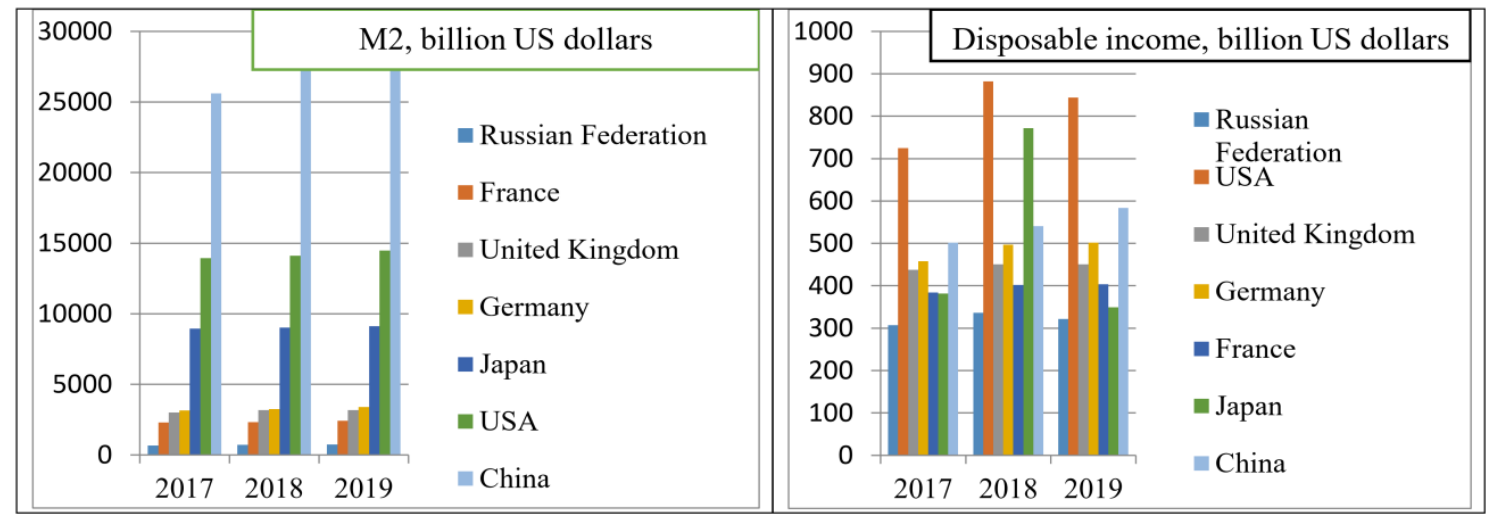

Figure 2. Rating of 7 countries worldwide by monetary aggregate M2 (billion US dollars) and disposable income of the population (billion US dollars)

In this case, in terms of indicator M2 (tab 2) and disposable income of the population, Russian Federation is in an unattractive position with very little progress, despite a rather high level of savings from GDP. Thus, the growth of M2 over three years amounted to $11 \%$, and the disposable income of the population increased by only $4 \%$. In the ranking of indicators listed above, Russia is in the last place among seven countries worldwide (Figure 2).

There is practically no alternative to bank deposits in the Russian financial market in terms of placing free cash funds by the population.

The advantages of banks in the Russian market are initially determined by the choice of a bank-oriented model of financial mediation, typical for Russia. The share of banking assets in the total volume of active representatives of the Russian financial market accounts for about $90 \%$. The remaining $10 \%$ are assets of non-bank financial and credit organizations [Bogoviz, 2019].

Table 3. Key performance indicators of the banking sector of the Russian Federation

\begin{tabular}{|c|c|c|c|c|}
\hline Indicator & $\mathbf{2 0 1 7}$ & $\mathbf{2 0 1 8}$ & $\mathbf{2 0 1 9}$ & $\begin{array}{c}\text { Deviation } \\
\mathbf{2 0 1 7 - 2 0 1 9}\end{array}$ \\
\hline $\begin{array}{c}\text { Capital of the } \\
\text { banking sector, } \\
\text { total, billion } \\
\text { rubles }\end{array}$ & 78121,2 & 84497,1 & 93538,3 & 15417,1 \\
\hline $\begin{array}{c}\text { The largest share } \\
\text { in assets: }\end{array}$ & 71,4 & 71,6 & 74,3 & 2,9 \\
\hline Loan debt,\% & 80 & 79,6 & 81,2 & 1,2 \\
\hline $\begin{array}{c}\text { The largest share } \\
\text { in liabilities: }\end{array}$ & 87,4 & 88 & 88,5 & 1,1 \\
\hline $\begin{array}{c}\text { Involved } \\
\text { funds, \% }\end{array}$ & 80,6 & 80 & 80,4 & $-0,2$ \\
\hline $\begin{array}{c}\text { Assets generating } \\
\text { direct income, } \%\end{array}$ & 763,2 & 827,6 & 1268,4 & 505,2 \\
\hline $\begin{array}{c}\text { Interest } \\
\text { generating } \\
\text { liabilities, } \%\end{array}$ & $\begin{array}{c}\text { Net profit, billion } \\
\text { rubles }\end{array}$ & 70 & & \\
\hline
\end{tabular}

According to the banking sector results, over the last period, all main indicators showed an increase (tab 3). So, the total capital of banks in 2019 Compared to 2017 increased by 15417.1 billion rubles, net profit for three years in relative terms increased by $66.2 \%$ [Gallyamova, 2018].

The priority role of banks in financial mediation does not impede the development of non-bank financial institutions (parabanks) and their increasing role in the financial services market, especially in terms of maintaining and increasing savings (Table 4).

Table 4. Key performance indicators of the non-banking financial sector (NFS) of the Russian Federation for 2017-2019

\begin{tabular}{|c|c|c|c|c|}
\hline Indicator & $\mathbf{2 0 1 7}$ & $\mathbf{2 0 1 8}$ & $\mathbf{2 0 1 9}$ & $\begin{array}{c}\text { Deviation } \\
\mathbf{2 0 1 7 - 2 0 1 9}\end{array}$ \\
\hline $\begin{array}{c}\text { Capital of the } \\
\text { NSF, total, } \\
\text { billion rubles }\end{array}$ & 1389,4 & 1512,2 & 1806,1 & 416,7 \\
\hline Assets & 7045,5 & 7996,5 & 8646,1 & 1600,6 \\
\hline $\begin{array}{c}\text { Interest } \\
\text { generating } \\
\text { liabilities,\% }\end{array}$ & 77,5 & 75,7 & 78,4 & 0,9 \\
\hline $\begin{array}{c}\text { Net profit, } \\
\text { billion rubles }\end{array}$ & 80,7 & 86,3 & 90,9 & 10,2 \\
\hline
\end{tabular}

The dynamics of the main indicators of the non-banking financial sector (microfinance organizations, non-governmental pension funds, professional participants of the RZB, etc.) over the last period highlighted the strengthening of the positions of NSFs representatives in the financial services market (Table 4).

Among the positive factors, the steadily growing assets and profits should be noticed. They are prerequisites for the stable functioning and development of the sector. Growing from year-to-year funds of the population on bank deposits and on accounts of the non-banking financial sector is the positive factor (Table $5)$. 
Table 5. Cash held in the financial sector of the Russian Federation in 2016-2018 (billion rubles)

\begin{tabular}{|c|c|c|c|c|}
\hline Indicator & $\mathbf{2 0 1 7}$ & $\mathbf{2 0 1 8}$ & $\mathbf{2 0 1 9}$ & $\begin{array}{c}\text { Deviation } \\
\mathbf{2 0 1 9}-\mathbf{2 0 1 7}\end{array}$ \\
\hline $\begin{array}{c}\text { Deposits of } \\
\text { individuals in the } \\
\text { banking financial } \\
\text { sector, total }\end{array}$ & 23674 & 24996 & 27156 & 3482 \\
\hline Including: & & & & \\
\hline demand deposits & 2989,5 & 3628,8 & 4593,7 & 1604,2 \\
\hline term deposits & 14597,9 & 15999,5 & 16784,3 & 2186,4 \\
\hline $\begin{array}{c}\text { in foreign } \\
\text { currency }\end{array}$ & 6086,6 & 5367,7 & 5788 & $-298,6$ \\
\hline $\begin{array}{c}\text { Allocated funds of } \\
\text { the population in } \\
\text { the non-banking } \\
\text { financial sector }\end{array}$ & 2300,6 & 3509,6 & 3717,6 & 1417 \\
\hline
\end{tabular}

However, the share of attracted resources of the population in the banking sector is $88 \%$ annually, only $12 \%$ goes to the non-banking sector (Figure 3 ).

The modern development of domestic financial institutions are taking place in the context of a worsening investment climate, the absence of clear and stable rules, the lack of reliable financial instruments, and tough regulatory standards. However, over the past few years, a steadily growing long-term trend in the investment industry in the non-banking financial sector has appeared. This indicates the interest of individual investors in financing investment processes in the domestic economy.

The results of the analysis of the Russian banks' current state, including population fundraising, allow us to build a framework of strategic advantages and disadvantages of their activities with ways to overcome existing problems and reveal the areas of development (Table 6).

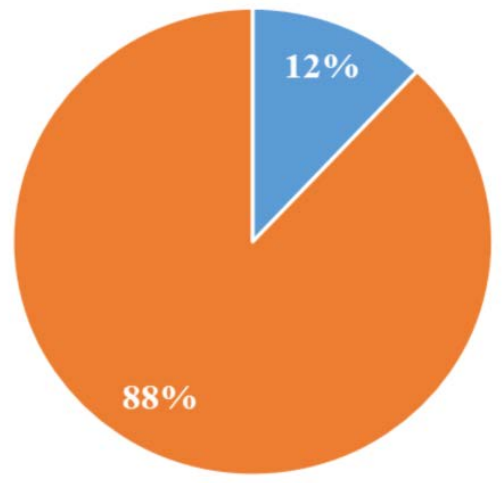

\section{- Banking financial sector $=$ Non-banking financial sector}

Figure 3. The structure of monetary funds of the Russian population in the banking and non-banking financial sector, $\%$

Table 7 summarizes the results of the strengths and weaknesses of non-banking financial intermediaries and the likely threats and opportunities for their development from a strategic perspective.

The development of the Russian banking and non-banking sector is associated with the scale and directions of investment activity of all economic entities. A special role in this process belongs to the further search for financing investment sources, which ultimately leads to the formation of an appropriate amount of savings that are the only source of investment resources and transformed at the macro level.

It should be noted that the investment potential of domestic households, despite the growth trend $(+1.6 \%$ $2019 / 2018$ ), is very low compared to the same indicator of savings, for example, in the USA: the ratio of the country's GDP is $4.5 \%$ to $18.7 \%$.

Table 6. SWOT analysis of the Russian banking sector.

\begin{tabular}{|c|c|}
\hline $\begin{array}{c}\text { Strengths } \\
\text { They occupy a major part of the financial services market. } \\
\text { Competitiveness. } \\
\text { High level of service quality. } \\
\text { A wide range of services offered. } \\
\text { Product Availability } \\
\end{array}$ & $\begin{array}{l}\text { Opportunities } \\
\text { Banking innovations development. } \\
\text { Improving the marketing strategy of promoting banking products on the } \\
\text { market. } \\
\begin{array}{c}\text { Development of a client base based on improving the financial literacy } \\
\text { of the population and the quality of customer service }\end{array}\end{array}$ \\
\hline $\begin{array}{c}\text { Weaknesses } \\
\text { Low level of capitalization. } \\
\text { Imperfect transfer pricing system for banking services. } \\
\text { The difficulty of attracting new customers. } \\
\text { Insufficient quality of the risk management system. }\end{array}$ & $\begin{array}{c}\text { Threats } \\
\text { Strengthening population mistrust. } \\
\text { Increase in the past due to obligations. } \\
\text { Decreased solvency of the population and enterprises. } \\
\text { The threat of capital outflow. } \\
\text { The growth of economic instability }\end{array}$ \\
\hline
\end{tabular}


Table 7. SWOT-analysis of the activities of non-bank financial institutions in Russia

\begin{tabular}{|c|c|}
\hline $\begin{array}{l}\text { Strengths } \\
\text { The ability to provide more affordable loan agreements. } \\
\text { The opportunity to invest in innovation projects of enterprises. } \\
\text { Stable growth of assets of joint investment institutions. } \\
\text { The expansion of the market of financial companies. } \\
\text { Stable growth of insurance reserves }\end{array}$ & $\begin{array}{c}\text { Opportunities } \\
\text { The development of banking innovation. } \\
\text { Improvement of marketing promotion strategy of Bank } \\
\text { products. } \\
\text { Development of client base through improved financial } \\
\text { literacy and quality customer service }\end{array}$ \\
\hline $\begin{array}{l}\text { Weaknesses } \\
\text { A limited number of financial instruments for investment and risk } \\
\text { diversification. } \\
\text { A limited number of sources of the base formed by non-Bank financial } \\
\text { intermediaries. } \\
\text { Unscrupulous behavior of some non-Bank financial intermediaries, which } \\
\text { creates in society the atmosphere of distrust of their reliability. } \\
\text { The imperfection of the legislative and regulatory framework of non-Bank } \\
\text { financial institutions and protection measures for the investor's rights and } \\
\text { interests. }\end{array}$ & $\begin{array}{l}\text { Threats } \\
\text { Strengthening macroeconomic instability in the country. } \\
\text { Further reduction of the effective financial services } \\
\text { demands of enterprises and households. } \\
\text { The decline in the non-Bank financial intermediaries’ } \\
\text { market segment. } \\
\text { A new wave of bankruptcies of non-Bank financial } \\
\text { intermediaries. }\end{array}$ \\
\hline
\end{tabular}

\section{Result and Discussion}

Several problems that affect the formation of the financial investment potential accompany the transformation process of savings into investment.

The long absence of effective mechanisms for small savings accumulation; permanent problems of various financial market entities (commercial banks, credit unions, etc.) lead to social distrust. To improve the situation, in our opinion, it is necessary to focus the government's activities on the following areas:

- Improvement of legal framework by implementing end-to-end protection of the individual investors' rights from the selection to the sales process. It will give an opportunity to increase the investors' interest in the purchase of financial market instruments. Forms and mechanisms of such protection should be first, information transparency of the Russian financial market; secondly, strict licensing and supervision of market participants; finally, the government establishment of centralized insurance funds for compensation of losses in case of bankruptcy of individual issuers of financial instruments;

- Increasing competition between financial institutions, which will lead to lower prices for individual financial services and reduce transaction costs when investing in financial tools. In addition, the competitive basis of the financial institution's sector will lead to improvement in the investments' quality parameters and prevent the market activity of inefficient financial intermediaries;

- Expansion of the range and characteristics of financial instruments can be a potential object of investment for individual investors. Via preventive measures, the government must create conditions for the growth of issuers' interest in attracting investments in financial instruments.

- Positive change in the general conditions of investment activity in the Russian financial market: firstly, to provide the concentration of financial instruments' trading via the organized trade and the activation of secondary circulation of financial instruments; secondly, to provide the development of financial market infrastructure, which will lead to the cost operations reducing; thirdly, to provide equitable development of all financial instruments and financial services.

At the same time, the effectiveness of the transformation of savings into investment depends on creating a favorable business environment and social development.

Prospects for investment growth in the domestic economy is:

- Accumulation of funds in the framework of the social and pension insurance system and their direction in the future long-term lending of investment activities;

- Broadening the base of investment resources directed to innovation through the mechanism of tax, customs, and regulatory policies;

- Intense development of the stock market investment process;

- Increasing investment activity of the population and ensuring guaranteed protection of their savings;

- The foundation of free funds' accumulation mechanism, particularly in venture capital funds;

- Reforming the taxation system to stimulate investment activity, etc.

In addition, with the aim of enhancing the households' role in savings' management, it should be provided educational and explanatory work with the population about the possibilities and benefits of financial instruments, as well as the expediency of the personal financial managers and financial consultants services, which will allow households to manage their own financial resources more effectively. Development of partnerships between the population and joint investment institutions, mutual funds, etc., will lead to improvement 
in quality and an increase in investment profitability. The financial institutions mentioned above are professional participants in the financial services market and more competent in the investment sphere than households.

\section{Conclusions}

The research was based on a statistical analysis of investment attractiveness based on the norm of economic viability to determine the tendencies of the development of business activity with the account to the prioritized choice made by households and business entities of the prioritized mixed strategies of the placement of temporarily spare financial assets. The results of the study revealed a strong and direct relationship between the share of temporarily available cash assets owned by households and businesses and the level of the expected cost-effectiveness of invested capital, indicating that the customer appeal of real-estate investment projects is increasing as the share of temporarily available cash assets rise. As a result, as accessible cash assets rise, so do investments in the entrepreneur sector, which is distinguished by a high-risk level conditioned by the use of fundamental innovations.

The results of the analysis of the Russian financial market development trends allow us to identify two main areas to reform:

- Improvement the activities of the regulator and increasing the effectiveness of the government supervision in the field of financial services markets;

- Protection of the financial services consumers' interests and restoring confidence in financial intermediaries.

To solve or reduce the severity of the above-mentioned problems, particular attention should be paid to the development of the modern and competitive infrastructure of domestic financial institutions. In this case, measures to improve the stability of financial intermediaries may be:

- Implementation of monetary policy based on inflation targeting, improving the monetary policy of the Russian Central Bank;

- Improving the communication strategy through the introduction of financial products;

- Implementation of measures to reduce the economy's dollarization level;

- Improving the regulation of the financial intermediaries' liquidity;

- Stimulating the development of long-term financial resources;

- Increasing the efficiency of the regulatory system and supervision in the financial services market;

- Establishing the quality monitoring of financial intermediaries' assets, their needs in supporting liquidity and capitalization;
Increasing transparency and stability of the financial market;

- Usage of effective mechanisms developed by international experience to clean the financial intermediaries' balances from distressed assets;

- Ensuring the dynamic development of the financial services markets' instruments and infrastructure;

- Stimulating the financial literacy and education of consumers and investors in the financial services market, as well as raising standards for protecting their rights and interests.

As it is known, the savings rate is the main indicator characterized the saving behavior of the population, indicating the unused share of household income, characterized the country's credit potential, allowing the economy to finance its activities and determine the conditions for future growth. In this case, the aim to increase the savings rate will allow the government to cope with cyclical fluctuations in the economy.

\section{REFERENCES}

[1] Alam, A., Nizam, R. S., \& Hidayat, M. T. (2021). The Role of Islamic Microfinance Institution in Empowering Indonesian Fishing Communities.

[2] Bagautdinova, I. V., Tokareva, G. F., \& Shalina, O. I. (2016). Modern trends in the financial intermediation in Russia. Ekonomika. Nalogi. Pravo= Economics. Taxes. Law, 9(5), 90-98.

[3] Bakharev, V. V., Kapustina, I. V., Mityashin, G. Y., \& Katrashova, Y. V. (2020). Ecologization of retail: An analysis of strategies. Siberian Journal of Life Sciences and Agriculture, 12(5), 79-96. doi:10.12731/2658-6649-2020-1 2-5-79-96

[4] Başok, E., \& Sayer, P. (2020). Language Ideologies, Language Policies and their Translation into Fiscal Policies in the US Perspectives of Language Education Community Stakeholders. Journal of Culture and Values in Education, 3(2), 54-80.

[5] Birru, Y. A. (2019). Ethiopian financial sector development. In The Oxford handbook of the Ethiopian economy. Oxford University Press.

[6] Bogoviz, A. V. (2019). Industry 4.0 as a new vector of growth and development of knowledge economy. In Industry 4.0: Industrial Revolution of the 21st Century (pp. 85-91). Springer.

[7] Deryagin, A., Krasnova, L., Sahabiev, I., Samedov, M., \& Shurygin, V. (2019). Scientific and educational experiment in the engineering training of students in the bachelor's degree program in energy production. SCOPUS-2019-8-8-SID85067871613.

[8] Dmitrieva, D., \& Romasheva, N. (2020). Sustainable Development of Oil and Gas Potential of the Arctic and Its Shelf Zone: The Role of Innovations. Journal of Marine Science and Engineering, 8(12), 1003. 
[9] Dudukalov, E., Spabekov, G. O., Kashirskaya, L. V., Sevbitov, A. V., Voronkova, O. Y., \& Vasyutkina, L. V. (2020). Fiscal goals of regulating the activities of the institute of controlled foreign companies in the digital economy. Dudukalov, EV, Spabekov, GO, Kashirskaya, LV, Sevbitov, AV, Voronkova, O. Yu. \& Vasyutkina, LV (2020). "Fiscal Goals of Regulating the Activities of the Institute of Controlled Foreign Companies in the Digital Economy”. Entrepreneurship and Sustainability Issues, 8(2), 972-983.

[10] Gallyamova, T. (2018). Peculiarities of modern monetary and credit policy of the Central Bank (Bank of Russia) of the Russian Federation. Экономика и Финансы (Украина), $1,5$.

[11] Globa, S. B. (2021). Russian Sovereign Wealth Fund. In Sovereign Wealth Funds, Local Content Policies and CSR (pp. 147-165). Springer.

[12] Goryainova, L., Maksimova, T., Zhdanova, O., \& Ermilova, M. (2020). Possible ways to attract private investment in a knowledge-based economy. E3S Web of Conferences, 159, 06013.

[13] IGNATOVA, T. V., OVCHARENKO, G. V., LARKINA, N. G., \& FILIMONTSEVA, E. M. (2019). Higher education impact onto development of innovative thinking of managers. Revista ESPACIOS, 40(21).

[14] Ivanova, V. N., Poltarykhin, A. L., Szromnik, A., \& Anichkina, O. (2019). Economic policy for country's digitalization: A case study. Entrepreneurship and Sustainability Issues, 7(1), 649.

[15] Ivanova, V., Poltarykhin, A., \& Szromnik, A. (2020). STATE REGULATION OF TARIFFS IN THE GAS SECTOR1. Journal of Security \& Sustainability Issues, 9(3).

[16] Kantarbayeva, A., \& Mustafin, A. (2020). A biologically inspired fluid model of the cyclic service system. Mathematical Modelling and Analysis, 25(4), 505-521.

[17] Karlsson, C., \& Tavassoli, S. (2018). Industrial policy in the post-industrial society: is the EU on the right track? In Governance and Political Entrepreneurship in Europe. Edward Elgar Publishing.

[18] Karwowski, E. (2018). Corporate financialization in South Africa: From investment strike to housing bubble. Competition \& Change, 22(4), 413-436.

[19] Kashirskaya, L. V., Sitnov, A. A., Davlatzoda, D. A., \& Vorozheykina, T. M. (2020). Knowledge audit as a key tool for business research in the information society. Entrepreneurship and Sustainability Issues, 7(3), 2299.

[20] Korableva, O. N., Mityakova, V. N., \& Kalimullina, O. V. (2020). Designing a decision support system for predicting innovation activity. Proceedings of the 22nd International Conference on Enterprise Information Systems ICEIS 2020, 619-625.

[21] Korshunova, S. E. (2020). The Development Of The Sphere Of Supervisory Activities Of The Bank Of Russia As A Mega-Regulator Of The Financial Market. Экономика и Бизнес: Теория и Практика, 7, 103-115.

[22] Lee, C.-C., \& Lin, C.-W. (2018). Economic growth, financial market, and twin crises. The Journal of International Trade \& Economic Development, 27(8), 937967.

[23] Leung, R., \& Ilsever, J. (2013). Review of evidence between corporate governance and mandatory IFRS adoption from the perspective of agency theory and information asymmetry. Universal Journal of Accounting and Finance, 1(3), 85-94. DOI: 10.13189/ujaf.2013.010301

[24] Magugu, J. W., Feng, S., Huang, Q., \& Ototo, G. O. (2018). Socio-economic factors affecting agro-forestry technology adoption in Nyando, Kenya. Journal of Water and Land Development, 39(1), 83-91.

[25] McCorkle, W. (2020). Problematizing Immigration Restrictions during COVID-19 in the Social Studies Classroom. Research in Social Sciences and Technology, 5(3), 1-24.

[26] Moșteanu, N. R. (2019). International Financial Markets face to face with Artificial Intelligence and Digital Era. Theoretical \& Applied Economics, 26(3).

[27] Movchan, I. B., \& Yakovleva, A. A. (2019). Approach to automation of field diagnosis data interpretation for localization of pitting in the pipeline wall. International Journal of Civil Engineering and Technology, 10(2), 15711581.

[28] Nikas, A., Lieu, J., Sorman, A., Gambhir, A., Turhan, E., Baptista, B. V., \& Doukas, H. (2020). The desirability of transitions in demand: Incorporating behavioural and societal transformations into energy modelling. Energy Research \& Social Science, 70, 101780.

[29] Nikolaeva, T. P., Panova, T. A., \& Vershinina, A. A. (2019). Specifics of the Microfinance Market Development in Russia. J. Advanced Res. L. \& Econ., 10, 625.

[30] Obura, J. M., \& Anyango, C. (2016). Moderating effect of interest rates on relationship between foreign exchange rate fluctuation and performance of Nairobi securities exchange market. Universal Journal of Accounting and Finance, 4(2), 27-34. DOI: 10.13189/ujaf.2016.040201

[31] Pogosyan, V. (2019). Change and variability of phenomena in complex social systems. Wisdom, 13(2), 95-103.

[32] Prischepa, O. M., Nefedov, Y. V., \& Ibatullin, A. K. (2020). Raw material source of hydrocarbons of the arctic zone of russia. Periodico Tche Quimica, 17(36), 506-526.

[33] Puryaev, A. (2020). About the Essence of Categories "Efficiency" and "Efficiency of the Investment Project." Proceeding of the International Science and Technology Conference" FarEastCon 2019", 643-651.

[34] Sembiyeva, L., Serikova, M., Satymbekova, K., Tulegenova, Z., Nurmaganbetova, B., \& Zhagyparova, A. (2021). Tax audit in innovative development of the energy sector of the economy: Gobal trends. Journal of Water and Land Development.

[35] Shynkaruk, L. V., Baranovska, I. V., \& Milman, L. M. (2018). Investment resources of households as a factor of economy modernization of Ukraine. Економічний Вісник Національного Гірничого Університету, 1, 16-24.

[36] Suryono, S., Surarso, B., Saputra, R., \& Sudalma, S. (2019). Real-time decision support system for carbon monoxide 
threat warning using online expert system. Journal of Applied Engineering Science, 17(1), 18-25.

[37] Takhumova, O. V., Kadyrov, M. A., Titova, E. V., Ushakov, D. S., \& Ermilova, M. I. (2018). Capital structure optimization in russian companies: problems and solutions. Journal of Applied Economic Sciences, 13(7), 1939-1944.

[38] Tolstolesova, L. A., Yumanova, N. N., Mazikova, E. V., Glukhikh, I. N., \& Vorobieva, M. S. (2019). Realization of PPP projects in the sector of energetics as a condition of a sustainable development of macroregions. Entrepreneurship and Sustainability Issues, 7(1), 263.

[39] Trotta, G. (2018). Factors affecting energy-saving behaviours and energy efficiency investments in British households. Energy Policy, 114, 529-539.

[40] Utama, R., \& Kunnawuttipreechachan, E. (2021). Dynamics of the Delayed Business Cycle Model with Expectation and General Saving Function.

[41] Vigliarolo, F. (2020). Towards an ontological reason law in economics: principles and foundations. Insights into
Regional Development, 2(4), 784-801.

[42] Yan, S., Ferraro, F., \& Almandoz, J. (2019). The rise of socially responsible investment funds: The paradoxical role of the financial logic. Administrative Science Quarterly, 64(2), 466-501.

[43] Yemelyanov, V., Nedelkin, A., \& Yemelyanova, N. (2019) Expert System Software for Assessing the Technical Condition of Critical Lined Equipment. International Scientific Siberian Transport Forum, 930-937.

[44] Yumashev, A. V., Fateminasab, S. M., Marjani, A., \& Lirgeshas, A. B. (2021). Development of computational methods for estimation of current efficiency and cell voltage in a Chlor-alkali membrane cell. Energy Sources, Part A: Recovery, Utilization, and Environmental Effects, $1-14$.

[45] Zadoia, O. A. (2017). Transformation of savings into investments: role of financial intermediarie. Науковий Вісник Національного Гірничого Університету, 2, 165170. 